\title{
Pengembangan Buku Penuntun Praktikum IPA SD Berbasis Keterampilan Proses Sainspada Mata Kuliah Praktikum IPA SDuntuk Mahasiswa Pendidikan Guru Sekolah Dasar (PGSD)
}

\section{Development of Elementary School Natural Science Practical Guidance Book Based on Science Process Skills in Elementary School Science Practice Course for Elementary School Teacher Education Students (PGSD)}

\author{
Tisrin Maulina Dewi \\ Program Studi Pendidikan Guru Sekolah Dasar Universitas Karimun, Indonesia \\ Koresponden: tisrinmaulinadewi@gmail.com
}

\begin{abstract}
Abstrak
Buku Penuntun Praktikum IPA SD Berbasis Keterampilan Proses Sains masih sangat dibutuhkan oleh Mahasiswa PGSD sebagai panduan dalam pelaksanaan praktikum. Penelitian ini bertujuan untuk mengetahui tingkat kelayakan buku penuntun Praktikum IPA SD berbasis keterampilan proses sains untuk mahasiswa PGSD. Jenis penelitian ini adalah penelitian pengembangan dengan model pengembangan produk Borg dan Gall, yang dimodifikasi sesuai kebutuhan. Subjek uji coba terdiri dari tim ahli materi, ahli desain, 1 dosen pengampu mata kuliah, 3 mahasiswa PGSD pada uji coba perorangan, 6 mahasiswa PGSD pada uji coba kelompok kecil dan 15 mahasiswa PGSD pada uji coba kelompok lapangan terbatas. Data tentang kualitas produk pengembangan ini dikumpulkan dengan angket. Hasil penelitian menunjukkan bahwa: (1) Validasi tim ahli materi berada pada kriteria "sangat baik" (84\%); (2) Validasi tim ahli desain berada pada kriteria "baik" (78\%); (3) Penilaian dosen pengampu mata kuliah berada pada kriteria "sangat baik" (84\%); (4) Respon mahasiswa berada pada kriteria "sangat baik" dengan nilai persentase sebesar 83\%, sehingga dapat disimpulkan bahwa produk pengembangan penelitian buku penuntun praktikum IPA SD berbasis keterampilan proses sains yang dikembangkan ini layak untuk digunakan sebagai bahan ajar oleh dosen dan mahasiswa Pendidikan Guru Sekolah Dasar (PGSD).
\end{abstract}

Kata Kunci : Keterampilan Proses Sains,Penelitian Pengembangan, Penuntun Praktikum

\begin{abstract}
SD science practical guidance book based on science process skills is still very much needed by PGSD students as a guide in practical implementation. This study aims to determine the expedience degree of elementary school natural science practical guidance book based on science process skills for elementary school teacher education students (PGSD). This type of research is the development of research with product development model Borg and Gall, modified as needed. The test subject consists of validator in material expert, validator in learning design expert, one of lecturer, 3 students of elementary school teacher education students in individual testing, 6 students of elementary school teacher education studentsin small test group testing and 15 students of elementary school teacher education students in group confined field trials. Data on quality of product development were collected by questionnaire. The results of this study showed that: (1) Validation of material expert is in very good criteria (84\%); (2) Validation of learning design expert is in good criteria (78\%); (3) Assesment studies of course lecturer are in very good criteria (84\%); (4) responses of students are in very good criteria (83\%), so it can concluded that elementary school natural science practical guidance book based on science process skills is fit for use as teaching material by lectures and students of elementary school teacher education (PGSD.
\end{abstract}

Keywords: Science Process Skills, Research and Development, Practical Guidance Book 


\section{PENDAHULUAN}

Peningkatan mutu guru SD menjadi salah satu kunci untuk meningkatkan mutu pendidikan. Dalam meningkatkan mutu guru SD, guru tidak hanya dituntut untuk memahami konsep teori saja tetapi juga dari segi keterampilan dan sikap dalam mata pelajaran. Pada jenjang SD, salah satu mata pelajaran yang memuat konsep teori, keterampilan dan sikap adalah mata pelajaran IPA. Djojosoediro (2012) menyatakan bahwa karakteristik IPA yang membedakannya dengan bidang ilmu lain antara lain 1) IPA mempunyai nilai ilmiah; 2) IPA merupakan suatu kumpulan pengetahuan yang tersusun secara sistematis, dan dalam penggunaannya secara umum terbatas pada gejala-gejala alam; 3) IPA merupakan pengetahuan teoritis yang diperoleh atau disusun dengan cara yang khas; 4) IPA merupakan suatu rangkaian konsep yang saling berkaitan dengan bagan-bagan konsep yang telah berkembang sebagai suatu hasil eksperimen dan observasi; dan 5) IPA meliputi empat unsur, yaitu produk, proses, aplikasi dan sikap.

Praktikum IPA SD merupakan salah satu mata kuliah inti dalam struktur kurikulum Program Studi Pendidikan Guru Sekolah Dasar (PGSD), Fakultas Keguruan dan Ilmu Pendidikan (FKIP) Universitas Karimun. Mata kuliah ini merupakan salah satu mata kuliah yang dianggap sulit oleh mahasiswa karena mahasiswa hanya terpaku pada konsep teori saja dan tidak paham tentang aspek keterampilannya. Hal ini menuntut kemampuan dosen untuk menyajikan konsep materi praktikum IPA SD yang tepat serta merancang skenario pembelajarannya sehingga mahasiswa bisa melakukan aktivitas belajar dengan lebih baik. Adapun masalah kedua pada perkuliahan praktikum IPA SD adalah dosen belum mampu untuk menerapkan pembelajaran yang diharapkan karena keterbatasan instrumen laboratorium dan media pendukung lainnya. Selain itu, mahasiswa juga menjadi kendala untuk mencapai pemahaman konsep perkuliahan praktikum IPA SD, yaitu mahasiswa kurang memiliki motivasi belajar, serta kemampuan awal mahasiswa yang tidak seragam. Semua permasalahan ini akan berakibat pada rendahnya penguasaan konsep mahasiswa pada mata kuliah praktikum IPA SD yaitu dengan rerata nilai mahasiswa 68.

Praktikum melatih mahasiswa untuk merencanakan kegiatan secara mandiri (afektif), melatih memecahkan masalah dari teori kedalam sebuah permasalahan yang lebih nyata (kognitif), serta dapat melatih penggunaan suatu instrumen (psikomotorik) (Susantini dkk, 2012). Kegiatan praktikum dianggap menjadi kebiasaan, karena mahasiswa hanya mengikuti 
petunjuk rutin, namun tidak menggunakan keterampilan proses. Padahal adanya keterampilan proses itu sangat penting dalam kegiatan praktikum karena keterampilan proses melibatkan kemampuan kognitif atau intelektual, manual dan sosial berdasarkan hasil dari sebuah pemikiran (Rajagukguk, 2016).

Penuntun praktikum merupakan pedoman peserta didik dalam menguji dan melaksanakan secara nyata sesuatu yang diperoleh berupa konsep dari teori. Menurut Nikmah dan Binadja (2015), mengemukakan bahwa diktat praktikum adalah buku penunjang kegiatan praktikum yang berisi materi dan serangkaian prosedur kerja yang akan dilakukan dalam praktikum, sehingga keberadaan diktat praktikum ini dapat mempengaruhi keberhasilan pembelajaran di laboratorium karena sebagai acuan peserta didik.

Penelitian Rajagukguk (2016) yang mengembangkan sebuah penuntun praktikum genetika berbasis keterampilan proses sains diperoleh hasil bahwa dengan penggunaan penuntun praktikum berbasis keterampilan proses sains dapat meningkatkan seluruh kemampuan keterampilan proses sains mahasiswa. Sehingga dengan penuntun praktikum berbasis keterampilan proses sains memiliki efek potensial terhadap hasil belajar mahasiswa.

Buku penuntun praktikum merupakan buku yang disusun untuk membantu memudahkan proses pelaksanaan praktikum yang didalamnya terdiri dari judul praktikum, tujuan, dasar teori, alat dan bahan, serta pertanyaan yang mengarah ke tujuan pelaksanaan praktikum. Menurut Klininc (2007) dalam Rajagukguk (2016) menyatakan bahwa penuntun praktikum merupakan fasilitas praktikum yang sudah digunakan sejak lama. Penuntun praktikum digunakan sebagai panduan tahapan-tahapan kerja praktikum bagi siswa maupun bagi guru sendiri.

Keterampilan proses sains menurut Karslih dan Sahin (2009) adalah fasilitas dasar yang membantu peserta didik untuk aktif dan membuat pembelajaran dialami langsung. Selanjutnya Dahar (2011) menambahkan bahwa keterampilan proses sains merupakan kemampuan peserta didik untuk menerapkan metode ilmiah dalam memahami, mengembangkan dan menemukan ilmu pengetahuan. Adanya keterampilan proses sains pada diri mahasiswa akan memudahkannya dalam menggali informasi yang lebih bermanfaat berupa fakta-fakta dan konsep, perkembangan sikap, nilai dan keterampilan berpikirnya juga akan berkembang (Wardani, 2010). Menurut Rustaman (2005) dalam Rajagukguk (2016) 
menyatakan bahwa keterampilan proses sains memiliki 11 indikator diantaranya: 1) Mengamati; 2) Mengelompokkan / klasifikasi; 3) Meramalkan; 4) Mengajukan pertanyaan; 5) Merumuskan hipotesis; 6) Merencanakan percobaan; 7) Menggunakan alat/bahan; 8)Menetapkan konsep; 9) Mengukur; 10) Menghitung dan 11) Berkomunikasi.

Kelebihan keterampilan proses sains dapat membantu mengembangkan ilmu pengetahuan, sehingga membawa peserta didik lebih memahami fakta dan konsep ilmu pengetahuan dengan baik, memberikan kesempatan kepada peserta didik bekerja dengan ilmu pengetahuan, membuat peserta didik menjadi belajar proses dan produk ilmu pengetahuan sekaligus (Zulaiha dkk, 2014). Adapun buku penuntun praktikum dalam penelitian ini merupakan buku penuntun praktikum IPA SD yang berbasis keterampilan proses sains. Penelitian ini bertujuan untuk mengetahui tingkat kelayakan buku penuntun Praktikum IPA SD berbasis keterampilan proses sains untuk mahasiswa PGSD.

\section{METODE PENELITIAN}

Penelitian ini di lakukan di Fakultas Keguruan dan Ilmu Pendidikan Universitas Karimun Jalan Canggai Puteri Kecamatan Tebing Kabupaten Karimun, dengan waktu penelitian mulai Oktober 2017 sampai Oktober 2018. Penelitian ini merupakanpenelitian pengembangan atau sering disebut Research and Development adalah suatu metode penelitian yang digunakan untuk menghasilkan produk tertentu dan menguji keefektifan produk tersebut (Sugiyono, 2015). Penelitian pengembangan buku penuntun praktikum IPA SD berbasis keterampilan proses sains ini menggunakan model pengembangan Borg \& Gall (Sugiyono, 2016).

Populasi dalam penelitian ini adalah seluruh mahasiswa Prodi Pendidikan Guru Sekolah Dasar (PGSD) dengan jumlah 89 mahasiswa dan sampel dalam penelitian ini adalah mahasiswa semester 6 Prodi PGSD berjumlah 24 orang mahasiswa. Teknik pengambilan sampel yang dipilih secara Purposive Random Sampling yaitu teknik pengambilan sampel yang digunakan dengan adanya tujuan khusus, yaitu karena mahasiswa sudah menerima mata kuliah konsep biologi SD, konsep fisika SD serta praktikum IPA SD. Data yang diambil dalam penelitian ini antara lain: (1) Kelayakan isi penuntun praktikum; (2) Kelayakan penyajian penuntun praktikum; (3) Keterampilan proses sains; (4) Desain kulit penuntun praktikum; (5) Tipografi kulit penuntun praktikum; (6) Desain isi penuntun praktikum; (7) 
Ilustrasi isi penuntun praktikum; (8) Data hasil tanggapan dosen terhadap penuntun praktikum; (9) Data hasil tanggapan mahasiswa terhadap penuntun praktikum.

Adapun instrumen pengumpulan data pada penelitian pengembangan ini berupa instrumen penilaian produk penuntun praktikum yang telah dikembangkan, yang terdiri dari validasi dari ahli materi, validasi dari ahli desain, lembar respon dosen mata kuliah serta lembar respon dari mahasiswa. Jenis data yang diperoleh dalam penelitian berupa data kualitatif yang diperoleh dari hasil penilaian kelayakan buku penuntun praktikum. data kualitatif hasil penelitian diubah menjadi data kuantitatif dengan aturan pemberian skor sesuai dengan yang dipaparkan Suparno (2011) untuk mempermudah menghitung skor ratarata setiap komponen penilaian, selanjutnya nilai setiap komponen dimaknai dengan kalimat bersifat kualitatif (Sugiyono, 2015).

\section{HASIL DAN PEMBAHASAN}

Hasil penelitian ini adalah produk berupa Buku Penuntun Praktikum IPA SD Berbasis Keterampilan Proses Sains untuk Mahasiswa Prodi Pendidikan Guru Sekolah Dasar (PGSD). Para ahli berupa tim ahli materi dan ahli desain memberikan penilaian terhadap produk yang dikembangkan dengan persentase nilai 84\% kategori sangat baik (Tabel 1).

Para ahli materi memberikan masukan terhadap buku penuntun praktikum yang dikembangkan berupa perbaiki susunan gambar yang ada pada tiap paragraf, tuliskan keterangan dan sumber pada gambar, gambar dibuat secara proporsional, pembahasan dibuat secara terperinci agar mudah dimengerti, kalimat yang ddigunakan pada konten harus lengkap dan sederhana, dan pergunakan istilah kalimat KPS yang mudah diketahui artinya.

Menurut Hersandi (2015) dalam Lestari dkk., (2018) menyatakan bahwa dalam membuat suatu bahan ajar hendaknyamenggunakan kalimat yang hanya memiliki makna tunggal pada setiap kalimat, singkat, jelas dan sederhana. Pada penelitian ini, ahli desain memberikan penilaian terhadap produk penuntun praktikum yang dikembangkan dengan kriteria baik dan persentase sebesar 78\% (Tabel 2).

Para ahli desain memberikan masukan terhadap penuntun pratikum yang dikembangkan pada beberapa bagian seperti setiap gambar diberi keterangan, keserasian atara teks dan gambar perlu diperhatikan sehingga kehadiran gambar akan memperjelas teks, 
proporsi gambar disediakan dengan ruang yang tersedia sehingga akan terkesan tidak dipaksakan, dan gambar harus sesuai dengan pesan yang akan diinformasikan. Hal ini bertujuan agar mahasiswa lebih tertarik untuk menggunakan buku penuntun praktikum. Minat membaca seseorang akan meningkat apabila gambar yang terdapat di dalam buku itu menarik (Mudjito, 2015).

Tabel 1.Analisis Penilaian Berdasarkan Ahli Materi

\begin{tabular}{|c|c|c|c|c|}
\hline Komponen & Indikator & $\begin{array}{c}\text { Jumlah } \\
\text { Item }\end{array}$ & $\begin{array}{l}\text { Rata-Rata } \\
(\%)\end{array}$ & Kriteria \\
\hline & Kesesuaian Konsep & 3 & 84 & Sangat Baik \\
\hline Kelayakan Isi & Kedalaman Konsep & 3 & 85 & Sangat Baik \\
\hline \multirow{3}{*}{ Penuntun Praktikum } & Keakuratan Materi & 10 & 82 & Sangat Baik \\
\hline & Materi Pendukung Perkuliahan & 3 & 81 & Sangat Baik \\
\hline & Teknik Penyajian & 6 & 84 & Sangat Baik \\
\hline \multirow{4}{*}{$\begin{array}{l}\text { Kelayakan Penyajian } \\
\text { Penuntun Praktikum }\end{array}$} & Kejelasan Kalimat & 2 & 85 & Sangat Baik \\
\hline & Kebahasaan & 2 & 83 & Sangat Baik \\
\hline & Penyajian dan pembelajaran & 3 & 85 & Sangat Baik \\
\hline & Kelengkapan penyajian & 3 & 82 & Sangat Baik \\
\hline & Mengamati & 2 & 86 & Sangat Baik \\
\hline & Mengklasifikasikan & 3 & 86 & Sangat Baik \\
\hline & Meramalkan & 2 & 86 & Sangat Baik \\
\hline Kelayakan & Mengajukan Pertanyaan & 2 & 85 & Sangat Baik \\
\hline Komponen & Merumuskan Hipotesis & 2 & 83 & Sangat Baik \\
\hline Keterampilan Proses & Merencanakan Percobaan & 3 & 84 & Sangat Baik \\
\hline \multirow[t]{6}{*}{ Sains } & Menggunakan Alat/Bahan & 2 & 84 & Sangat Baik \\
\hline & Menetapkan Konsep & 2 & 83 & Sangat Baik \\
\hline & Mengukur & 2 & 86 & Sangat Baik \\
\hline & Menghitung & 1 & 81 & Sangat Baik \\
\hline & Berkomunikasi & 4 & 85 & Sangat Baik \\
\hline & Rata-Rata & & 84 & Sangat Baik \\
\hline
\end{tabular}

Tabel 2. Analisis Penilaian Berdasarkan Ahli Desain

\begin{tabular}{|c|c|c|c|}
\hline Aspek Penilaian & Jumlah Item & Persentase Rata-Rata (\%) & Kriteria \\
\hline Desain kulit & 5 & 76 & Baik \\
\hline Tipografi Kulit & 4 & 77 & Baik \\
\hline Desain Isi & 11 & 79 & Baik \\
\hline Ilustrasi Isi & 4 & 80 & Baik \\
\hline Rata-Rata & & 78 & Baik \\
\hline
\end{tabular}

Hasil respon tentang produk yang dikembangkan yang diberikan kepada Dosen mata kuliah mendapatkan kategori sangat baik dengan rata-rata penilaian sebesar 84 (Tabel 3). Dari kedua belas indikator tersebut dapat menunjukkan bahwa produk yang dikembangkan sangat baik dan dapat membantu dosen ketika mengajar mata kuliah praktikum IPA SD. Hal 
ini sesuai dengan penelitian Gagne (1979) dalam Dewi (2016) bahwa buku ajar yang terbaik di dunia tidak akan memenuhi fungsi dan perannya jika buku tersebut tidak disukai oleh seorang pengajar.

Tabel 3. Analisis Respon Dosen Mata Kuliah

\begin{tabular}{|c|c|c|c|}
\hline Indikator & Jumlah Item & Persentase Rata-rata (\%) & Kriteria \\
\hline Tampilan PP & 3 & 85 & Sangat Baik \\
\hline Kesesuaian SK/KD & 1 & 83 & Sangat Baik \\
\hline Kesesuaian tujuan & 1 & 84 & Sangat Baik \\
\hline Kejelasan kalimat & 1 & 80 & Baik \\
\hline Kebahasaan & 3 & 80 & Baik \\
\hline Petunjuk penggunaan & 1 & 86 & Sangat Baik \\
\hline Tata tertib dan petunjuk K3 & 2 & 90 & Sangat Baik \\
\hline Ilustrasi gambar & 2 & 80 & Baik \\
\hline Ukuran dan jenis huruf & 2 & 87 & Sangat Baik \\
\hline Urutan prosedur kerja & 1 & 85 & Sangat Baik \\
\hline Memotivasi & 1 & 86 & Sangat Baik \\
\hline KPS & 11 & 87 & Sangat Baik \\
\hline Rata-rata & & 84 & Sangat Baik \\
\hline
\end{tabular}

Adapun mahasiswa yang memberikan respon terhadap buku penuntun praktikum yang dikembangkan ini adalah melalui uji coba perorangan, uji coba kelompok kecil dan uji coba kelompok lapangan terbatas (Tabel 4).

Tabel 4. Respon Mahasiswa terhadap Produk yang Dikembangkan

\begin{tabular}{lcl}
\hline \multicolumn{1}{c}{ Indikator Penilaian dari } & Persentase Rata-rata (\%) & \multicolumn{1}{c}{ Kriteria } \\
\hline Uji coba Perorangan & 79 & Baik \\
Uji coba kelompok kecil & 83 & Sangat Baik \\
Uji coba kelompok lapangan terbatas & 88 & Sangat Baik \\
\hline Rata-Rata & 83 & Sangat Baik \\
\hline
\end{tabular}

Data respon mahasiswa terhadap buku penuntun praktikum yang dikembangkan mengalami peningkatan yaitu terjadi peningkatan $4 \%$ dari uji coba perorangan ke uji coba kelompok kecil, dan $5 \%$ juga dari uji coba kelompok kecil ke uji coba kelompok lapangan terbatas. Hal ini menunjukkan bahwa buku penuntun praktikum yang dikembangkan dapat membantu dan menarik bagi mahasiswa. Hal ini sesuai dengan pendapat Prasetyo (2011) yang menyatakan bahwa produk hasil pengembangan yang sudah diakukan revisi berdasarkan masukan dan saran dari validator layak digunakan jika desain produk telah 
mendapat penilaian minimal memiliki kriteria baik dari pihak validator. Oleh karena itu, buku penuntun praktikum IPA SD yang telah dikembangkan dapat dijadikan sebagai sumber bahan ajar yang dapat digunakan oleh dosen pengampu mata kuliah dan mahasiswa.

\section{KESIMPULAN}

Adapun kesimpulan dari penelitian ini adalah telah berhasil dikembangkan produk berupa buku penuntun praktikum IPA SD berbasis keterampilan proses sains untuk mahasiswa PGSD menggunakan model pengembangan Borg dan Gall. Produk ini mendapatkan penilaian yang sangat baik dari validator ahli materi dengan persentase sebesar $84 \%$, kategori baik sebesar $78 \%$ dari validator ahli desain, $84 \%$ kategori sangat baik dari dosen mata kuliah dan $83 \%$ kategori sangat baik dari mahasiswa. Hasil ini menunjukkan bahwa produk yang dikembangkan layak digunakan dalam perkuliahan praktikum IPA SD sebagai salah satu sumber bahan ajar.

\section{REFERENSI}

Dahar, R.W., 2011. Teori-Teori Belajar dan Pembelajaran. Erlangga, Jakarta

Dewi, T.M., 2016. Pengembangan Modul Pencemaran Lingkungan Berbasis Islam-Sains untuk Siswa Kelas X Madrasah Aliyah/MA. (Tesis). Program Pascasarjana, Universitas Negeri Medan, Medan.

Djojosoediro, W., 2012. Modul-1 Hakikat IPA dan Pembelajaran IPA SD. Pengembangan Pembelajaran IPA SD. Hal 15-60. Diunduh tanggal 21 Agustus 2018. http://pjjpgsd.unesa.ac.id/dok/1/.Modul-1HakikatIPAdan PembelajaranIPA.pdf.

Karslih F., dan Sahin, C., 2009. Developing Worksheet Based on Science Process Skill: Factors Affecting Solubility. Asia-Pasific Forum on Science Learning and Teaching, Vol. 10(1): 1-12

Lestari, W. D, Hasnunidah, N., Marpaung, R.R.T., 2018. Pengembangan Buku Penuntun Praktikum Sistem Organisasi Kehidupan dengan Model Argument-Driven Inquiry (ADI). Jurnal Bioterdidik: Wahana Ekspesi Ilmiah, Vol 6 (3):1-10

Mudjito, 2015. Pembinaan Minat Baca. Universitas Terbuka, Jakarta.

Nikmah, R. dan Binadja, A., 2015. Pengembangan Diktat Praktikum Berbasis Guided Discovery-Inquiry Bervisi Science, Environment, Technology, and Society. Jurnal Inovasi Pendidikan Kimia 9(1): 1506-1516.

Prasetyo, Z. K., 2011. Pengembangan Perangkat Pembelajaran Sains Terpadu untuk Meningkatkan Kognitif, Keterampilan Proses, Kreativitas serta Menerapkan Konsep Ilmiah Peserta Didik. Laporan Penelitian. Program Pascasarjana, Universitas Negeri Yogyakarta, Yogyakarta. 
Rajagukguk, I., 2016. Pengembangan Buku Penuntun Praktikum Genetika Berbasis Keterampilan Proses Sains. [Tesis]. Program Pascasarjana, Universitas Negeri Medan, Medan.

Sugiyono, 2015. Metode Penelitian Pendidikan Pendekatan Kuantitatis, Kualitatif dan $R \& D$ Cetakan. Alfabeta, Bandung.

Sugiyono, 2016. Metode Penelitian dan Pengembangan (Research and Development). Alfabeta, Bandung.

Suparno, 2011. Pengembangan Bahan Ajar Mata Diklat Adaptif Berbasis Web Based Learning pada Sekolah Menengah Kejuruan Jurusan Teknik Bangunan. Jurnal Teknologi dan Kejuruan, 34(1): 61-70.

Susantini, E., Thamrin M. H., Isnawati., dan Lisdiana, L., 2012. Pengembangan Petunjuk Praktikum Genetika untuk Melatih Keterampilan Berpikir Kritis. Jurnal Pendidikan IPA Indonesia, 1(2): 102-108.

Wardani, 2010. Penelitian Tindakan Kelas.Universitas Terbuka, Jakarta.

Zulaiha, Hartono, dan Ibrahim, A.R., 2014. Pengembangan Buku Penuntun Praktikum Kimia Hidrokarbon Berbasis Keterampilan Proses Sains di SMA. Jurnal Pendidikan Kimia, 2014 (1) 1: 87-93. 